\title{
Pelatihan Kewirausahaan Melalui Usaha Kue Dengan Bahan Dasar Ubi Kayu
}

\author{
Dahmiri $^{1)}$, Yuliusman $^{2)}$, Muhammad Amin $^{3)}$, Musyayaddah $^{4)}$, Arsyadt $^{5)}$ \\ ${ }^{1,2)}$ Dosen Fakultas Ekonomi dan Bisnis Universitas Jambi \\ ${ }^{3,4,5)}$ Dosen Fakultas Hukum Universitas Jambi
}

\begin{abstract}
Abstrak: Pegabdian pada masyarakat ini bertujuan untuk membangkitkan minat para pemuda di Kecamatan Pelawan Kabupaten Sarolangun dalam berwirausahadan memberi penyuluhan terhadap kurangnya kemampuan.Pengabdian ini hanya memfokuskan mengenai Peningkatan pengetahuan tentang kewirausahaan, peningkatan pengetahuan tentang berkelompok yang baik, peningkatan keterampilan objek dalam membuat produk, Peningkatan kemampuan mengelola usaha dalam situasi persaingan yang mendekati situasi bisnis nyata yang dinamis dan peningkatan kemampuan mengelola usaha sebenarnya dalam situasi persaingan yang nyata yang dinamis. Metode pengabdian yang akandigunakan adalah ceramah, diskusi, audio visual, simulasi dan praktik. Kegiatan yang dilakukan adalah melakukan penyuluhan kewirausahaan dan praktik membuat produk berupa kue dangan bahan dasar ubi kayu terhadap pemuda di Kecamatan Pelawan Kabupaten Sarolangun.Hasil Kegiatan penyuluhan dan pelatihan menumbuhkan budaya wirausaha anggota Karang Taruna dan mendapatkan respon yang positif dari para peserta, yang terdiri dari para anggota dan pengurus Karang Taruna di Kecamatan Pelawan Kabupaten Sarolangun.Hal ini ditunjukkan dari antusiasnya peserta mengikuti kegiatan ini dari awal sampai berakhirnya kegiatan ini, juga dari semangatnya peserta mengikuti kegiatan secara aktif.
\end{abstract}

Kata kunci : Kewirausahaan, Karang Taruna.

\section{PENDAHULUAN}

\subsection{Analisis Situasi}

Pertumbuhan pengangguran di Provinsi Jambi beberapa tahun ini, umumnya dan di Kabupaten Sarolangun khususnya, akan bergerak lebih cepat dari bertambahnya lapangan kerja. Bahkan akan menjadi masalah yang sangat serius bagi Provinsi Jambi, apabila tidak ditangani dengan sungguh-sungguh. Penyebab pengangguran di Provinsi Jambi setidaknya ada 3 hal, yaitu pertumbuhan angkatan kerja, migrasi tenaga kerja dari daerah lain dan tutupnya perusahaan-perusahaan Jambi yang berbasis bahan baku kayu.

Terbatasnya ketersediaan lapangan kerja dibandingkan dengan jumlah pencari kerja yang selalu bertambah setiap tahun, maka perlu ada solusi dalam rangka mengatasi pengangguran. Hal ini harus segera dicarikan solusinya agar menghindari dampak yang lebih besar dari ledakan angka pengangguran tersebut.

Anggota karang taruna sangat potensial untuk didorong menekuni bidang wiraswasta atau menjadi wirausaha.Wirausahawan dapat menciptakan kemakmuran bagi sekelompok orang dan juga harus memberikan nilai positif bagi masyarakat luas (Suseno, 2003).

Kemampuan individu dalam berinteraksi secara efektif dengan lingkungan dan memberi pengaruh pada orang lain demi mencapai tujuan dalam konteks sosial tertentu yang disesuaikan dengan budaya, lingkungan, situasi yang dihadapi serta nilai yang dianut oleh individu disebut sebagai kompetensi social. (Hughes dalam Topping dkk, 2000).

Kabupaten Sarolangun sebagai sebuah kabupaten yang baru terbentuk banyak dihadapkan pada berbagai persoalan termasuk masalah pengangguran, terutama para pemuda yang berada di desa-desa. Kecamatan Pelawan Kecamatan Pelawan termasuk kecamatan yang besar dan memiliki jumlah pemuda yang banyak masih belum memiliki pekerjaan tetap. Oleh karena itu salah satu pemecahan masalah ini adalah melalui wirausaha. 
Melihat kenyataan di atas, sudah saatnya kita memikirkan upaya-upaya dalam rangka mengatasi pengangguran yang semakin membengkak ini. Upaya ini dapat dilakukan oleh berbagai pihak baik pemerintah maupun masyarakat umum. Pemerintah dapat melakukan kegiatan pelatihan melalui Dinas Tenaga Kerja. Masyarakat umum juga dapat berpartisipasi dalam melakukan kegiatan pemberdayaan masyarakat. Salah satu upaya yang dapat dilakukan oleh masyarakat misalnya melakukan pelatihan keterampilan wirausaha.

Meng \& Liang (1996), merangkum pandangan beberapa ahli, dan mendefenisikan wirausaha sebagai: (a) Seorang inovator (b) Seorang pengambil risiko atau a risk-taker (c) orang yang mempunnyai misi dan visi (d) Hasil dalam pengalaman masa kanak-kanak (e) Orang yang memiliki kebutuhan berprestasi tinggi. (f) Orang yang memiliki locus of control internal.

Zimmerer \& Scarborough (1998) mengemukakan ciri wirausaha yang berhasil, yang dibagi kedalam tiga kategori, sebagai berikut (1) bersifat proaktif, yaitu inisiatif yang tinggi dan asertif; (2). orientasi prestasi,yaitu melihat kesempatan dan bertindak langsung, orientasi efisiensi, menekankan pekerjaan dengan kualitas tinggi, perncana yang sistematis, monitoring; (3). komitmen dengan pihak lain, yaitu komitmen yang tinggi pada pekerjaan dan menyadari pentingnya hubungan bisnis yang mendasar.

Universitas Jambi sebagai lembaga pendidikan juga turut peduli terhadap masalah pengangguran yang ada di Provinsi Jambi umumnya dan Kabupaten Sarolangun Khususnya. Kegiatan yang dapat dilakukan misalnya menumbuhkan keterampilanberwirausaha pada anggota karang taruna, agar mampu untuk membuka usaha sendiri di bidang makanan tradisional setelah dibekali berbagai pengetahuan kewirausahaan.

Tim Pengabdian sebagai salah satu unsur masyarakat dapat berperan aktif dalam upaya peningkatan kualitas Sumber Daya Manusia Jambi, merasa terpanggil untuk melaksanakan salah satu tugas Tri Dharma Perguruan Tinggi yaitu Pengabdian kepada masyasakat dengan memberikan pendidikan dan pelatihan menumbuhkan keterampilan berwirausaha bagi Karang Taruna Di Kabupaten Sarolangun khususnya dalam usaha kuedengan bahan dasar ubi kayu, (Kue adalah kudapan atau makanan ringan yang bukan makanan utama: http://id.wikipedia.org/wiki/Kue).

Program Pengabdian Kepada Masyarakat diharapkan untuk dapat melahirkan wirausaha-wirausahan baru melalui rangkaian kegiatan perencanaan, proses sampai kepada implementasi proses produksi dan pemasaran makanan tradisional pada kelompok Karang Tarunadi Kecamatan Singkut Kabupaten Sarolangun Jambi. Kegiatan ini maerupakan solusi dalam rangka peningkatan kesejahteraan masyarakat khususnya pemuda anggota kelompok Karang Taruna.

\subsection{Permasalahan Mitra}

Rendahnya minat anggota karang taruna di Kecamatan Singkut Kabupaten Sarolangun dalam berwirausaha, masih sedikitanggota Karang Tarunadi Kecamatan Singkut Kabupaten Sarolangun yang bisa membuat kue dengan bahan dasar ubi kayu dan kurangnya kemampuan anggota Karang Tarunadi Kecamatan SingkutKabupaten Sarolangun dalam berusaha atau menjadi wirausaha. 


\subsection{Solusi}

Permasalahan utama yang dihadapi oleh karang taruna di Kecamtan Singkut Kabupaten Saroangun adalah tingginya pengangguran yang ada di kalangan pemuda anggota kelompok Karang Taruna.Potensi yang dapat ditemukan adalah besarnya jumlah pemuda atau sumber daya manusia yang ada di desa tempat pengabdian.Selain itu, antusiasme cukup tinggi dikalangan karang taruna untuk memiliki keterampilan berusaha.

Solusi yang ditawarkan dalam pengabdian ini adalah melakukan penyuluhan dan pelatihan keterampilan membuat kue untuk menumbuhkan jiwa wirausaha. Untuk memperoleh hasil yang optimal, perencanaan proses pelatihan perlu dilakukan beberapa tahapan yaitu ; (1) dibuat gambar rencana atau gambar kerja, (2)menentukan jenis produk yang akan dibuat (3) merencanakan usaha yang akan jalankan, (4) menghitung kebutuhan peralatan dan jumlah modal (5) penyuluhan dan pelatihan membuat produk (6) menyusun rencana usaha terpadu.

\subsection{Target Luaran}

Adapun yang ditargetkan menjadi luaran dari kegiatan ini adalah :

a. Kecakapan Hidup :

- Indikator kecakapan personal :anggota Karang Taruna mampu membuat kue dengan bahan dasar ubi kayu, menyusun rencana usaha dan tumbuh budaya berwirausaha.

- Indikator kecakapan sosial :anggota Karang Tarunamemiliki kemampuan bekerjasama, memiliki kemampuan berkomunikasi dan negosiasi dalam pemasaran hasil usaha.

- Indikator kecakapan akademik :anggota Karang Tarunamemiliki kemampuan mengidentifikasi masalah-masalah dalam bisnis dan mampu memecahkan masalah bisnis tersebut.

\section{b. Kecakapan wirausaha :}

- Prediksi usaha : indikatornya adalah setiap orang memiliki komitmen untuk membuka usaha kue dengan bahan dasar ubi kayu.

- Pengembangan usaha : indikatornya adalah produk/jasa yang mereka hasilkan mempunyai mutu yang baik, yang ditunjukkan dengan membandingkan produk/jasa tersebut dengan pesaing yang sudah ada.

- Kemandirian usaha : indikatornya adalah keberanian (memiliki tekad dan semangat tinggi) untuk membuka usaha kue dengan bahan dasar ubi kayu.

\section{METODE PELAKSANAAN}

\subsection{Metode Penerapan Kegiatan}

a. Ceramah

Metode ini dimaksudkan untuk memberikan materi pengetahuan tentang prinsip-prinsip rencana usaha dan teori tentang kue dengan bahan dasar ubi kayu yang ada di Kecamatan Singkut Kabupaten Sarolangun.

b. Diskusi :

Metode ini dimaksudkan untuk melatih peserta dalam menyampaikan ide-ide dan pokokpokok pikiran yang berkaitan dengan rencana usaha pembuatan kue, termasuk mempresentasikan rencana usaha. 
c. Audio Visual.

Alat elektronik audio visual akan dimanfaatkan untuk menampilkan profil pengusaha sebagai salah satu cara untuk meningkatkan minat dan motivasi mitra terhadap dunia kewirausahaan.

d. Simulasi.

Berlatih bertindak sebagai pengusaha yang akan menjalankan usaha kue dengan bahan dasar ubi kayu. Situasi dan kondisi bisnis, ekonomi, sosial, politik di daerah dimana usaha dijalankan akan dipaparkan secara rinci dalam simulasi tersebut. Situasi dan kondisi tersebut berubah setiap periode simulasi yang harus diantisipasi oleh anggota Karang Taruna. Berdasarkan situasi dan kondisi tersebut, peserta akan saling berkompetisi untuk mencapai tujuan perusahaan dengan alat ukur keberhasilan (kinerja) adalah tingkat profitabilitas (Return on Equity).

e. Praktik

Pada bagian ini anggota Karang Tarunaakan dilatih untuk praktik perencanaan pembuatan kue dengan bahan dasar ubi kayu, praktek proses pembuatan, praktek mengemas dan praktek pemasaran serta membuat laporan keuangan. Pada kegiatan praktek ini akan disiapkan semua alat dan bahan yang berkenaan dengan kue bahan dasar ubi kayu.

\subsection{Kegiatan Pendahuluan}

\section{a. Tahap Perencanaan}

Tahap perencanaan dilakukan dengan menyusun berbagai hal yang akan disiapkan untuk pelaksanaan kegiatan seperti rencana lokasi, materi, jadwal kegiatan dan narasumber.

b. Tahap Pendekatan

Pada tahap pendekatan dilakukan kegiatan berupa kunjungan ke lokasi pengabdian sebelum pelaksanaan kegiatan pengabdian.Tahap ini bertujuan untuk menjalin kerjasama sehingga pelaksanaan pengabdian berjalan lancar.

\subsection{Peserta Pengabdian}

Peserta yang ikut dalam kegiatan pengabdian pada masyarakat ini adalah anggota Karang Taruna di Kecamatan Pelawan dengan jumlah peserta sebanyak 20 orang.(Pedoman Dasar KARANG TARUNA diatur dalam Peraturan Menteri Sosial RI Nomor 83/HUK/2005).

\subsection{Waktu dan Tempat pengabdian}

Pengabdian pada masyarakat ini direncanakan akan dilaksanakan pada bulan 19 Agustus 2018 di Kecamatan Singkut Kabupaten Sarolangun.

\section{HASIL DAN PEMBAHASAN}

\subsection{Kegiatan Pendahuluan}

Dalam tahap ini dilakukan kegiatan sebagai berikut :

1. Tahap Perencanaan

Pada tahap ini dilakukan penyusunan agenda kegiatan pengabdian yang mencakup persiapan dan penyusunan materi yang akan disampaikan, lokasi pengabdian, dan sasaran pengabdian. 
2. Tahap Pendekatan

Pada tahap ini tim pengabdian melakukan diskusi dengan ketua Karang Taruna Desa Batu Putih Kecamatan Pelawan Kabupaten Sarolangun.

\subsection{Pelaksanaan Pengabdian}

a. Personalia Pengabdian.

Pengabdian pada masyarakat ini dalam pelaksanaannya terdiri dari Tim Pengabdian Kepada Masyarkat Universitas Jambi yang berjumlah 2 (dua) orang dengan susunan tim sebagai berikut :

Ketua: Dr. Dahmiri, SE.,MM

Anggota : 1. Yuliusman, SE.,M.SI.,Ak

2. Muhammad Amin, SH.,MH

3. Dra. Musyayaddah, M.Pd.I.

4. Arsyadt, SH.,MH.,M.Kn

b. Peserta Pengabdian

Sesuai dengan sasaran yang ingin dicapai, peserta yang ikut dalam kegiatan" Penyuluhan Kewirausahaan Bagi Anggota Karang Taruna Di Kecamatan Pelawan Kabupaten Sarolangun ini berjumlah 20 orang.

c. Waktu Pengabdian

Pelaksanaan pengabdian dilaksanakan pada Hari Sabtu tanggal 19Agustus 2018.

d. Tempat Pengabdian

Pelaksanaan kegiatan dilaksanakan di Desa Batu Putih Kecamatan Pelawan Kabupaten Sarolangun.

e. Jenis Kegiatan

Adapun jenis kegiatan yang dilakukan adalah pelatihan membuat membuat kue ddngan bahan dasar ubi kayu, penyuluhan tentang kewirausahaan, membuat rencana usaha, simulasi usaha.

\subsection{Materi}

Dalam melaksanakan kegiatan penyuluhan kewirausahaan ini Tim pengabdian menyampaikan materi secara garis besar dibagi dalam 5 (lima) pokok bahasan ; pelatihan membuat kue dangan bahan dasar ubi kayu, Perspektif Kewirausahaan, Evaluasi Peluang Usaha, Simulasi Wirausaha, dan Rencana Usaha. Pertama :pelatihan membuat kue dengan bahan dasar ubi kayu mulai dari pemilihan jenis kue yang akan dibuat, cara membuat dan pemasaran hasil. Kedua :Perspektif Kewirausahaan dirancang untuk memperkenalkan konsep dan teori kewirausahaan, profil wirausaha yang didasarkan pada perilaku, karakteristik, dan faktor-faktor lainnya yang membedakan antara wirausaha dan manajer.Ketiga : Evaluasi Peluang Usaha dilakukan dengan mengidentifikasi peluang usaha yang sesuai dengan tujuan dan karakteristik wirausaha dari masing-masing peserta.Keempat : Simulasi Wirausaha dirancang untuk memberi pengalaman kepada peserta dalam mengelaola usaha. Dalam kegiatan simulasi ini, peserta dibagi kedalam beberapa kelompok yang akan mengelola usaha dalam situasi persaingan yang mendekati situasi bisnis nyata yang dinamis. Peserta dituntut untuk membuat strategi kinerja masing-masing kelompok usaha.Kelima : Rencana Usaha merupakan tugas akhir dari materi kewirausahaan. Setiap peserta diharuskan untuk mempersiapkan dan menyusun rencana usaha terpadu berdasarkan ide awal yang telah diidentifikasi dan dievaluasi pada pokok bahasan kedua (Evaluasi Peluang usaha).Rencana usaha ini menuntut peserta untuk mengumpulkan dan menganalisis informasi, kemudian 
merencanakan aspek-aspek pemasaran, operasional produksi, manajemen, sumber daya manusia, dan keuangan.

\subsection{Hasil Kegiatan}

a. Memberikan pengetahuan dan keterampilan membuat kue dengan bahan dasar ubi kayu.

b. Melatih anggota karang taruna peserta pelatihan dalam perencanaan usaha secara tepat.

c. Menumbuhkembangkan minat mahasiswa menjadi wirausaha dalam bidang yang mereka minati masing-masing

d. Memberikan pengalaman nyata dalam mengimplementasi aspek-aspek manajemen usaha.

Para peserta penyuluhan dan pelatihan mengikuti kegiatan dengan baik dan antusias. Hal ini dapat terlihat dari besarnya minat anggota karang taruna dalam kegiatan pelatihan, penyuluhan, diskusi, kegiatan praktik yang mereka lakukan, keseriusan peserta ketika menampilkan profil wirausaha yang sukses dan ketertarikan mereka pada bahasan mengenai peluang usaha makanan tradicional dan rencana usaha makanan tradisional.

Harapan peserta pelatihan dan penyuluhan ini adalah supaya dilakukan bimbingan lebih lanjut melalui pendampingan terhadap usaha yang mereka jalankan, selain itu diharapkan adanya penyuluhan sejenis yang dilakukan secara periodik dan melibatkan instansi terkait seperti Dinas Tenaga Kerja, Pihak Perbankan, Dinas Perdagangan dan Perindustian dan lainlain.

\section{KESIMPULAN}

Kegiatan penyuluhan menumbuhkan budaya wirausaha anggota Karang Taruna yang dilakukan oleh tim pengabdian ini mendapatkan respon yang positif dari para peserta, yang terdiri dari para anggota dan pengurus Karang Taruna Desa Batu Putih dan Desa Rantau Tenang Kecamatan Pelawan Kabupaten Sarolangun.Hal ini ditunjukkan dari antusiasnya peserta mengikuti kegiatan ini dari awal sampai berakhirnya kegiatan ini, juga dari semangatnya peserta mengikuti kegiatan secara aktif.

\section{SARAN}

Diharapkan dari kegiatan penyuluhan dan pelatihan Menumbuhkan budaya wirausaha anggota Karang Taruna ini peserta dapat benar-benar menerapkan pengetahuan yang telah diperoleh, yang pada akhirnya dapat membawa dampak yang positif bagi semua peserta, yaitu dengan terciptanya usaha-usaha baru di bidang yang diminati masing-masing yang dibangun oleh masing-masing anggota karang taruna atau peserta kegiatan.

\section{DAFTAR PUSTAKA}

http://id.wikipedia.org/wiki/Kue

Meng, LA dan Liang TW, 1996, Entrepreneur, Enterpreneurship and Entreprising Culture, Paris. Addison-Wisley Company.

Peraturan Menteri Sosial RI Nomor 83/HUK/2005 Tentang Pedoman Dasar Karang Taruna. 
Suseno, Hg., T. W. 2003. Pemberdayaan ekonomi rakyat melalui UKM dan entrepreneurship di kalangan pengusaha kecil.Jurnal Widya Manajemendan Akuntansi.

Topping, K., William, B., Elizabeth, A. H. 2000.Social Competence.The Social Construction of the Concept.The Handbook of Emotional Intelligence Jossey_Bass Inc: California.

Zimmerer, TW dan Scarborough, NM, 1998, Essential of entrepreneur nad Small Business Management 2th Prentice Hall 